\title{
Mild Biamidine-Transfer Conditions for the Synthesis of Aliphatic Biguanides
}

\author{
Rostyslav Bardovskyi ${ }^{\searrow a}$ \\ Marie Fabre ${ }^{\triangleright a}$ \\ Cyril Ronco*a ${ }^{*}$ \\ Rachid Benhida*a,b (1) \\ a Université Côte d'Azur, ICN, UMR 7272 CNRS, 06108 Nice, \\ France \\ cyril.ronco@univ-cotedazur.fr \\ rachid.benhida@univ-cotedazur.fr \\ ${ }^{b}$ Mohamed VI Polytechnic University, UM6P, 43150 BenGuerir, \\ Morocco \\ $\diamond$ These authors contributed equally
}

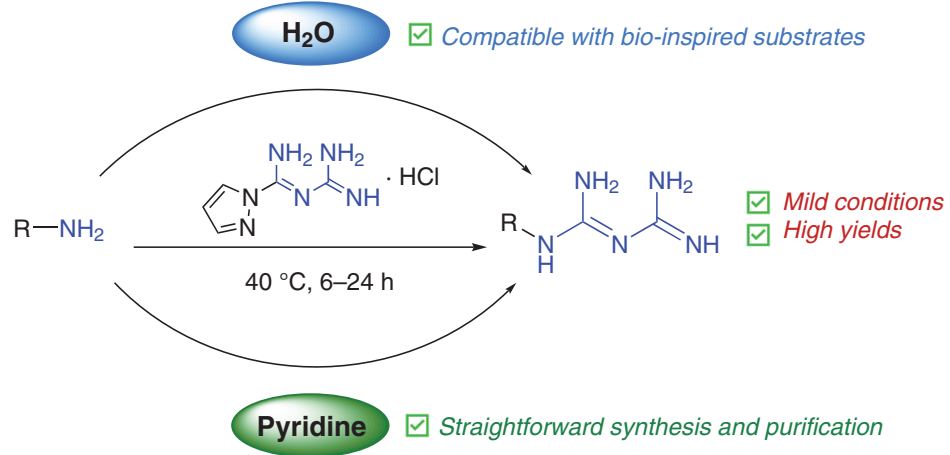

Pyridine $\square$ Straightforward synthesis and purification
Received: 27.07.2021

Accepted: 06.08.2021

Published online: 28.10 .2021

DOI: 10.1055/a-1681-4544; Art ID: so-2021-d0038-op

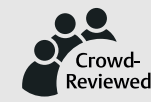

License terms: $c(0) \$$

(c) 2021. The Author(s). This is an open access article published by Thieme under the terms of the Creative Commons Attribution-NonDerivative-NonCommercial-License, permitting copying and reproduction so long as the original work is given appropriate credit. Contents may not be used for commercial purposes or adapted, remixed, transformed or built upon. (https://creativecommons.org/licenses/by-nc-nd/4.0/)

Abstract This study focuses on the development of new synthetic pathways to monosubstituted biguanides from amines. An exhaustive comparison of the conditions and reagents used for biamidine transfer was performed. New reagents were synthesized and optimized conditions for the synthesis of substituted biguanides under mild conditions were developed. Eventually, two high-yielding and straightforward protocols for the transfer of a biamidine group to various amines are proposed and their scope and limitations have been explored. These conditions include: i) a direct chromatography-free procedure and ii) an ecofriendly procedure in water compatible with bioinspired molecules. They are particularly efficient for the demanding conversion of aliphatic amines.

Key words biguanide, biamidine transfer, mild conditions, biocompatible protocol, guanidine derivatives

Biguanides are a class of compounds of great interest with wide applications in catalysis, superbase chemistry, as organometallic ligands, as well as a broad range of bioactivities such as antidiabetic (metformin and its analogues), antimalarial, antiseptic (chlorhexidine), antiviral, and more recently anticancer properties. ${ }^{1}$ Indeed, the biguanide function displays attractive properties since it features strong organic basicity, Lewis basicity, and represents a potential pharmacophore related to its particular structure with five heteroatoms and five $\mathrm{H}$-bonding sites modulated through several tautomeric forms. Meanwhile, these features render the synthesis and isolation of the biguanide derivatives sometimes tricky, due to their highly polar nature and com- plexation properties. ${ }^{2,3}$ The transformation of an amine to the corresponding biguanide derivative is particularly interesting. Precedents in the literature are scarce and basically rely on mixing an amine and cyanoguanidine under harsh conditions and high temperatures above $100{ }^{\circ} \mathrm{C}$ (even neat) in the presence of hydrochloric acid. ${ }^{3-6}$ The conversion of aliphatic amines is especially demanding, and some improvements have been proposed recently such as the replacement of $\mathrm{HCl}$ by iron trichloride ${ }^{7}$ or the use of silylamines. ${ }^{8,9}$ Nevertheless, conditions remain harsh and prolonged heating is still necessary. ${ }^{10,11}$ Alternatively, the preactivation of cyanoguanidine has been described through the use of $\mathrm{N}$-(diaminomethylene)-1H-pyrazole-1-carboximidamide hydrochloride (1a) $)^{2,12-16}$ or $S$-methylguanylisothiouronium iodide $(\mathbf{1 b})^{2,17}$ as biamidine-transfer reagents. However, these conditions suffer from low to moderate isolation yields, long reaction times, and/or harsh conditions. Therefore, no general protocol exists for this transformation, especially for aliphatic amines. In this context, the purpose of this study is to compare exhaustively the conditions and reagents used for the transfer of a biamidine group, propose new ones, and identify the problems related to this transformation. Mild straightforward reaction conditions suitable for various amines have been developed, including a protocol in water compatible with biological media. The study of the scope and limitations has demonstrated broad applicability for the synthesis of diverse biguanides under very smooth conditions.

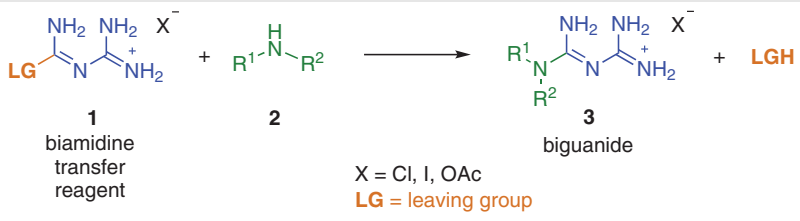

Scheme 1 Biguanide formation with biamidine-transfer reagents 
The conversion of amines into monosubstituted biguanides consists of the addition of a biamidine group to the amine. This can be achieved either by a direct addition of the amine to cyanoguanidine, which requires harsh reaction conditions or by using a biamidine-transfer reagent. The latter comprises a biamidine moiety linked to a leaving group to allow the transfer by an addition-elimination process (Scheme 1). As the nature of the leaving group was predicted to have a major influence on the reactivity, six potential reagents with different leaving groups were synthesized (Figure 1 ). From those, only $\mathbf{1 a}$ and $\mathbf{1} \mathbf{b}$ were described to produce biguanides whereas $\mathbf{1 e}$ is a new molecule. Briefly, reagents 1a, 1c, and 1e were synthesized by addition of a heterocycle to cyanoguanidine in the presence of hydrochloric acid in water under reflux or at $80{ }^{\circ} \mathrm{C}$ for $3-24 \mathrm{~h}$ with $65 \%, 44 \%$, and $25 \%$ yields, respectively. ${ }^{18} S$-Methyl derivative $\mathbf{1 b}$ was prepared from 2 -imino-4-thiobiuret and methyl iodide in $91 \%$ yield. ${ }^{19}$ Phenolic derivate $\mathbf{1 d}$ was obtained from cyanoguanidine dihydrochloride in phenol as solvent at $70{ }^{\circ} \mathrm{C}$ for $3 \mathrm{~h}$ in $33 \%$ yield. ${ }^{20}$ Finally, $\mathrm{N}$-guanyl-Omethylisourea hydroacetate (1f) was synthesized in two steps from cyanoguanidine in methanol under reflux for $2 \mathrm{~h}$ in the presence of copper acetate monohydrate, then the product was released from the copper complex following hydrogen sulfide treatment, with a $46 \%$ overall yield. ${ }^{21}$ These procedures provided after suitable washings the pure desired biamidine derivatives as salt form.

$$
\text { (1) }
$$

Figure 1 Synthesized biamidine-transfer reagents

With these reagents 1a-f in hand, we screened different reaction conditions on a model transformation of UV-absorbing benzylamine to the corresponding benzylbiguanide (Figure 1). Reagent $\mathrm{N}$-amidinopyrazole-1-carboxamidine hydrochloride (1a) was first used to compare the effect of additives and solvent nature on the conversion. The temperature was set up to $25^{\circ} \mathrm{C}$ in DMF with the aim to develop a new procedure under mild reaction conditions. The addition of DIPEA to the reaction did not have a significant effect compared to the control experiment without additive, whereas the addition of 1.0 equivalent of hydrochloric acid, triflic acid, or trifluoroacetic acid prevented the reaction (Table 1, entries 1-3). Performing the reaction in the presence of copper acetate also did not show any improvement (entry 4). As a result, additive-free conditions were chosen, which led to the most efficient and cleanest transformations.

\begin{tabular}{|c|c|c|c|c|c|}
\hline Entry & Reagent & Solvent & Additive & Equiv & $\begin{array}{l}\text { Conver- } \\
\text { sion }(\%)\end{array}$ \\
\hline 1 & $1 \mathrm{a}$ & DMF & - & - & 19 \\
\hline 2 & 1a & DMF & DIPEA & 1.1 & 18 \\
\hline 3 & $1 a$ & DMF & $\begin{array}{l}\text { HClor TFA } \\
\text { or TfOH }\end{array}$ & 1 & 0 \\
\hline 4 & $1 a$ & DMF & $\mathrm{Cu}(\mathrm{OAc})_{2}$ & 0.1 & 15 \\
\hline 5 & 1a & $\mathrm{AcOH}$ & - & - & 0 \\
\hline 6 & 1a & acetone & - & - & $0,5^{\mathrm{b}}$ \\
\hline 7 & 1a & NMP & - & - & 5 \\
\hline 8 & $1 \mathrm{a}$ & DMA & - & - & 7 \\
\hline 9 & 1a & acetonitrile & - & - & $32^{\mathrm{b}}$ \\
\hline 10 & 1a & $\mathrm{EtOH}$ & - & - & 40 \\
\hline 11 & $1 a$ & $\mathrm{MeOH}$ & - & - & 45 \\
\hline 12 & $1 a$ & pyridine & - & - & 51 \\
\hline 13 & $1 \mathrm{a}$ & $\mathrm{H}_{2} \mathrm{O}$ & - & - & 53 \\
\hline 14 & $1 \mathrm{a}$ & pyridine & - & - & $67^{c}$ \\
\hline 15 & $1 b$ & pyridine & - & - & $53^{c}$ \\
\hline 16 & $1 b$ & pyridine/toluene (1:1) & - & - & $64^{c}$ \\
\hline 17 & $1 \mathrm{~b}$ & pyridine/toluene (1:9) & - & - & $58^{c}$ \\
\hline
\end{tabular}

Table 1 Effect of Additives and Solvent ${ }^{\mathrm{a}}$

${ }^{a}$ All reactions were performed with $0.8 \mathrm{mmol}$ of benzylamine, $0.88 \mathrm{mmol}$ of the corresponding reagent in $4 \mathrm{~mL}$ of solvent, stirred for $6 \mathrm{~h}$ at $25^{\circ} \mathrm{C}$ and monitored by $\operatorname{HPLC}(\lambda=254 \mathrm{~nm})$.

b Solubility issues with formation of a suspension.

c All reactions were performed with $0.5 \mathrm{mmol}$ of benzylamine, $0.55 \mathrm{mmol}$ of the corresponding reagent in $1 \mathrm{~mL}$ of solvent, stirred for $5 \mathrm{~h}$ at $25^{\circ} \mathrm{C}$, and monitored by HPLC $(\lambda=254 \mathrm{~nm})$.

To get further insight on the solvent effect, several polar solvents were studied for this reaction (Table 1). Alcohols proved more beneficial than DMF, with respective conversions of $40 \%$ and $45 \%$ in ethanol and methanol, compared to $19 \%$ in DMF. Interestingly, the most preferable solvents were found to be pyridine and water, which showed higher solubility properties than alcohols, and demonstrated higher conversions of $51 \%$ and $53 \%$, respectively (entries $1,10-$ 13). Pyridine showed the highest conversion rate and the easiest product recovery by simple precipitation and washings of the reaction mixture. Water also showed interesting results and seems to be attractive as biocompatible and nontoxic solvent for the development of a green procedure.

For the next optimization step, we selected pyridine as a solvent and increased the reagent concentration from 0.20 $\mathrm{mmol}$ to $0.50 \mathrm{mmol}$ of reagent per $\mathrm{mL}$ of solvent, leading to an increase of the conversion from $51 \%$ to $67 \%$ (entries 12 , 14). S-Methyl-guanylisothiouronium iodide $\mathbf{1 b}$ proved to be somewhat less efficient in pyridine (entry 15), while the addition of toluene as a co-solvent led to conversion improvement (entries 16,17). As for reagent 1a, the product formation was not observed because of reagent insolubility in pyridine/toluene mixtures. Overall, the conditions of en- 
tries 14 and 16, respectively, reagent $\mathbf{1 a}$ in pyridine and reagent $\mathbf{1 b}$ in pyridine/toluene (1:1), turned out to be the best and were selected for the next optimization stages.

The performance of the different biamidine-transfer reagents 1a-f was screened in the two optimal solvents: water and pyridine (Table 2). As expected, reagent $\mathbf{1 f}$ (entry 6) allowed the formation of only traces of product as it contains a poor leaving group (methoxy). Benzotriazole derivative 1e (entry 5) showed a moderate conversion in pyridine but only traces of product in water. The most reactive compound proved to be 1d (entry 4), but its reactivity led to concomitant degradation in the solvent and the overall conversion was low. Decreasing the temperature to enhance the stability of 1d allowed reaching $60 \%$ conversion, but only after a long reaction time (7 days). Compound 1c (entry 3 ) is an analogue of pyrazole derivative 1a with two methyl groups, which surprisingly showed low conversion efficacy. S-Methyl derivative $\mathbf{1 b}$ (entry 2) demonstrated good conversion in pyridine, which is decreased in water. As a result, this survey revealed the best results for $\mathbf{1 a}$ in both solvents (entry 1 ), as well as $\mathbf{1 b}$ in pyridine. It is worth noting that reactions using $\mathbf{1 a}$ are easier to workup and purify than with $\mathbf{1 b}$. In addition, they avoid the release of toxic, flammable, and strong odoring methanethiol.

Table 2 Comparison of the Biamidine-Transfer Reagents in Pyridine and Water ${ }^{\mathrm{a}}$

\begin{tabular}{lll}
\hline Entry & $\mathrm{R}$ & Conversion (\%) \\
& Pyridine & $\mathrm{H}_{2} \mathrm{O}$ \\
\hline
\end{tabular}

\begin{tabular}{|c|c|c|c|}
\hline 1 & $1 a$ & 48 & 50 \\
\hline 2 & 1b & 43 & 15 \\
\hline 3 & 1c & 26 & 20 \\
\hline 4 & $1 \mathrm{~d}$ & 17 & 28 \\
\hline 5 & $1 e$ & 34 & 0 \\
\hline 6 & $1 \mathrm{f}$ & 0 & 1 \\
\hline
\end{tabular}

${ }^{a}$ All reactions were performed with $0.8 \mathrm{mmol}$ of benzylamine, $0.88 \mathrm{mmol}$ of the corresponding reagent in $4 \mathrm{~mL}$ of solvent, stirred for $5 \mathrm{~h}$ at $25^{\circ} \mathrm{C}$, and monitored by HPLC $(\lambda=254 \mathrm{~nm})$.
Finally, we studied the influence of concentration, temperature, and equivalents of reactants on the formation of benzylbiguanide hydrochloride (Table 3 ). Increasing the concentration of $1 \mathrm{a}$ from $0.2 \mathrm{~mol} / \mathrm{L}$ to $1.0 \mathrm{~mol} / \mathrm{L}$ had a great influence, enhancing therefore the yield from $51 \%$ to $73 \%$. Further concentration of 1a solution was not possible because of its saturation threshold in pyridine. Next, we moved the number of equivalents of benzylamine at a constant concentration of $1.0 \mathrm{~mol} / \mathrm{L}$ of $1 \mathrm{a}$. At 1.0 equivalent of benzylamine, we observed $1 \%$ of side products from selfcondensation or condensation with product leading to polyguanidines formation. Interestingly, the use of increased amounts of benzylamine completely eliminated the formation of side products leading to higher yields. A good compromise was found with the use of 1.5 equivalents of amine. As the obtained product is a salt form, the excess of amine could be easily removed by a simple washing. With the optimized conditions in hand, we explored the effect of temperature on the reaction efficiency using 1a in pyridine and $\mathbf{1 b}$ in pyridine/toluene $(1: 1)$. For both reagents, we found that $40{ }^{\circ} \mathrm{C}$ is the optimal temperature, given the conversion rate, yields, and the formation of low amounts of side products. Overheating reaction mixture over $40{ }^{\circ} \mathrm{C}$ promoted the formation of undesired products (ca. $5 \%$ ), whereas at $25{ }^{\circ} \mathrm{C}$ the conversion was clean but required a longer reaction time of up to 2 days. Eventually, optimized conditions proved to be the use of 1.5 equivalents of amine at a concentration of $1.0 \mathrm{~mol} / \mathrm{L}$ at $40{ }^{\circ} \mathrm{C}$.

To study the scope and limitations of the conditions developed (1a in pyridine, $\mathbf{1} \mathbf{a}$ in water and $\mathbf{1} \mathbf{b}$ in 1:1 pyridine/toluene), several alkyl and dialkyl amines, substituted benzylamines, L-phenylalanine and aniline were used as substrates (Table 4). Alkyl and dialkyl amines were converted into the corresponding biguanides with excellent conversions (91-99\%) and good to excellent isolated yields (69$96 \%)$ for both 1a based methods. Only the reactions with butylamine and hexylamine were slower (12-24 h) which could be ascribed to steric hindrance. Different substituted benzylamines were also isolated in good yields 70-95\%, without significant effect of the substitution pattern on the conversion. The formation of phenylbiguanide proved less efficient and the protocol in water is clearly preferred with $68 \%$ isolated yield after 22 h reaction, compared to $44 \%$ after 6 days in pyridine. Likewise, mainly for solubility reasons, the protocol in water was the most efficient to convert Lphenylalanine into its biguanide analogue in 53\% isolated yield (for this substrate, the procedure was modified with the addition of 1.0 equivalent of DIPEA and 1.0 equivalent of amino acid). Generally, despite good conversion rates with $S$-methyl derivative $\mathbf{1 b}$, the workup and isolation often were less direct than with 1a, often requiring chromatography methods to afford the biguanides with high purity. Considering the necessity of using a gas trap to deal with 
Table 3 Effect of Concentration, Equivalents of Amine and Temperature ${ }^{a}$

\begin{tabular}{|c|c|c|c|c|c|c|}
\hline Reagent & Solvent & Amine (equiv) & Concentration $(\mathrm{mol} / \mathrm{L})^{\mathrm{b}}$ & Temp $\left({ }^{\circ} \mathrm{C}\right)$ & Time (h) & Conversion (\%) \\
\hline $1 a$ & pyridine & 1.0 & 0.2 & 25 & 6 & 51 \\
\hline $1 \mathbf{a}$ & pyridine & 1.0 & 0.5 & 25 & 6 & 68 \\
\hline $1 \mathbf{a}$ & pyridine & 1.0 & 1.0 & 25 & 6 & 73 \\
\hline $1 \mathbf{a}$ & pyridine & 1.0 & 1.0 & 25 & 3 & 52 \\
\hline $1 a$ & pyridine & 1.1 & 1.0 & 25 & 3 & 56 \\
\hline $1 a$ & pyridine & 1.2 & 1.0 & 25 & 3 & 59 \\
\hline $1 a$ & pyridine & 1.5 & 1.0 & 25 & 3 & 65 \\
\hline $1 \mathbf{a}$ & pyridine & 2.0 & 1.0 & 25 & 3 & 68 \\
\hline $1 a$ & pyridine & 1.0 & 1.0 & 25 & 5 & 64 \\
\hline $1 a$ & pyridine & 1.0 & 1.0 & 30 & 5 & 83 \\
\hline $1 a$ & pyridine & 1.0 & 1.0 & 40 & 5 & 91 \\
\hline $1 a$ & pyridine & 1.0 & 1.0 & 50 & 5 & 92 \\
\hline $1 b$ & pyridine/toluene (1:1) & 1.0 & 1.0 & 25 & 5 & 70 \\
\hline $1 b$ & pyridine/toluene (1:1) & 1.0 & 1.0 & 30 & 5 & 75 \\
\hline $1 b$ & pyridine/toluene (1:1) & 1.0 & 1.0 & 40 & 5 & 86 \\
\hline $1 b$ & pyridine/toluene (1:1) & 1.0 & 1.0 & 50 & 5 & 91 \\
\hline
\end{tabular}

all reactions were monitored by $\operatorname{HPLC}(\lambda=254 \mathrm{~nm})$.

${ }^{\mathrm{b}}$ Concentration in mol of reagent dissolved per $\mathrm{L}$ of solvent.

Table 4 Scope and Limitations of the Conditions Developed on a Panel of Amines ${ }^{\mathrm{a}}$

\begin{tabular}{|c|c|c|c|c|c|c|c|c|c|}
\hline \multirow{2}{*}{$\begin{array}{l}\text { Solvent } \\
\text { Amine }\end{array}$} & \multicolumn{3}{|r|}{$\mathrm{Cl}^{-}$} & \multicolumn{3}{|r|}{$\mathrm{Cl}^{-}$} & \multicolumn{3}{|c|}{ Pyridine/toluene $(1: 1)_{1 \mathbf{b}}^{\mathrm{NH}_{\mathrm{S}}^{\mathrm{NH}_{2} \mathrm{I}^{-}}}$} \\
\hline & Time (h) & Conversion (\%) & Yield (\%) $)^{\mathrm{b}, \mathrm{c}}$ & Time (h) & Conversion (\%) & Yield (\%) & Time (h) & Conversion (\%) & Yield $(\%)^{b, c}$ \\
\hline benzylamine & 6 & 99 & 93 & 6 & 97 & 96 & 6 & 95 & 82 \\
\hline 4-chlorobenzylamine & 6 & 94 & 86 & 6 & 96 & 75 & 6 & 97 & nd \\
\hline 4-methylbenzylamine & 6 & 96 & 87 & 6 & 95 & 70 & 6 & 98 & nd \\
\hline 4-nitrobenzylamine & 6 & 99 & 90 & 6 & 98 & 93 & 6 & 97 & nd \\
\hline 4-methoxybenzylamine & 6 & 95 & 95 & 6 & 96 & 82 & 6 & 98 & nd \\
\hline ethylamine & 6 & 99 & 75 & 12 & 97 & 82 & 6 & 98 & nd \\
\hline butylamine & 24 & 95 & 86 & 12 & 96 & 77 & 6 & 98 & 54 \\
\hline hexylamine & 24 & 98 & 86 & 12 & 97 & 92 & 6 & 98 & nd \\
\hline morpholine & 6 & 96 & 83 & 6 & 97 & 91 & 6 & 97 & 82 \\
\hline$N$-methylpiperazine & 6 & 99 & 83 & 6 & 97 & 96 & 6 & 96 & 97 \\
\hline$N$-methylbenzylamine & 6 & 98 & 69 & 22 & 96 & 96 & 6 & 91 & nd \\
\hline aniline & 144 & 44 & nd & 22 & 71 & 68 & 6 & 0,1 & nd \\
\hline L-phenylalanine $^{d}$ & 96 & 0 & nd & 24 & 94 & 53 & 6 & 10 & nd \\
\hline
\end{tabular}


methanethiol evolution, the reagent $\mathbf{1 b}$ seems less preferable for this reaction. Contrarily, $\mathrm{N}$-(diaminomethylene)- $1 \mathrm{H}$ pyrazole-1-carboximidamide hydrochloride (1a) reacted efficiently and provided products in hydrochloride salt form with high yields and purity after a simple workup.

In summary, we developed herein a new synthetic method based on the use of biamidine-transfer reagents to efficiently convert amines into the corresponding guanidines. We proposed and compared six potential reagents and concluded that $\mathrm{N}$-(diaminomethylene)-1H-pyrazole-1carboximidamide hydrochloride (1a) is the best in terms of both efficiency and practicability. Moreover, we showed that the choice of solvent, concentration, and temperature are key parameters. The optimal conditions were achieved either in water or pyridine, affording smooth transformation of various amines into biguanides with high yields up to $96 \%$. The method with pyridine showed fast workup, requiring only a washing step even if it seems not applicable for amino acids and arylamines. Interestingly, the procedure in water showed very good efficiency for all tested amines under green conditions (water, no additive, temperature range: $25-40{ }^{\circ} \mathrm{C}$ ). As a result, this protocol will be compatible with sensitive or bioinspired substrates like peptides, aminosugars, or amine-bearing nucleotide analogues.

All the commercially available products from chemical providers were used without purification. Solvents were purchased from Sigma Aldrich. All chemicals were purchased from Aldrich, Fisher or Alfa Aesar. ${ }^{1} \mathrm{H}$ and ${ }^{13} \mathrm{C}$ NMR spectra were recorded on a Bruker Advance $200 \mathrm{MHz}$ spectrometer or Bruker Advance $400 \mathrm{MHz}$. The reactions were followed by HPLC analysis on a JASCO PU-2089 apparatus with the following method: EC 125/4 NUCEODUR HILIC, $5 \mu \mathrm{m}$. UV detection: 254 and $280 \mathrm{~nm}$. Eluent A: water with $0.1 \mathrm{M}$ of TEAB buffer ( $\mathrm{pH}$ 7). Eluent $\mathrm{B}: \mathrm{CH}_{3} \mathrm{CN}$ : $20 \%$ A over $1 \mathrm{~min}, 20 \% \mathrm{~A}$ to $60 \% \mathrm{~A}$ over $12 \mathrm{~min}$, $60 \%$ A for 6 min then from $60 \%$ A to $20 \%$ A over $0.5 \mathrm{~min}(20 \mathrm{~min}$ in total).

\section{Procedures for the Synthesis of the Biamidine-Transfer Reagents}

\section{N-Amidinopyrazole-1-carboxamidine Hydrochloride (1a)}

To a solution of pyrazole $(20.0 \mathrm{~g}, 0.294 \mathrm{~mol})$ in water $(44 \mathrm{~mL})$ was added hydrochloric acid $37 \%$ ( $25.9 \mathrm{~mL}, 0.294 \mathrm{~mol})$ and dicyandiamide (24.7 g, $0.294 \mathrm{~mol}$ ), and the mixture was stirred at $80{ }^{\circ} \mathrm{C}$ for $6 \mathrm{~h}$. The resulting colorless solution was slowly cooled to r.t., and colorless crystals of product appeared. These were filtered, washed with acetone and dried at air. White crystalline solid $(39.5 \mathrm{~g}, 0.209 \mathrm{~mol}, 65 \%)$. ${ }^{1} \mathrm{H}$ NMR (400 MHz, DMSO- $d_{6}$ ): $\delta=8.38$ (br s, $2 \mathrm{H}$ ), 8.34 (dd, $J=2.8,0.7$ $\mathrm{Hz}, 1 \mathrm{H}$ ), 8.28 (br s, $4 \mathrm{H}$ ), 7.87 (d, $J=1.5 \mathrm{~Hz}, 1 \mathrm{H}$ ), 6.58 (dd, $J=2.8,1.6$ $\mathrm{Hz}, 1 \mathrm{H}), 3.44(\mathrm{~s}, 2 \mathrm{H})$. Protocol adapted from the literature ${ }^{18}(50 \%)$, improved to $65 \%$.

\section{S-Methyl-guanylisothiouronium Iodide (1b)}

As described. ${ }^{19}$ Briefly, iodomethane was added dropwise to a suspension of 2-imino-4-thiobiuret (Aldrich) in 100\% ethanol while stirring at r.t. The reaction flask was shaken at $37{ }^{\circ} \mathrm{C}$ for $2 \mathrm{~h}$. The solvent was removed by evaporation, and the residue was washed with cold diethyl ether to give a solid, which was collected by filtration and used without further purification. White, crystalline solid $(39.5 \mathrm{~g}$, $0.209 \mathrm{~mol}, 91 \%$ ). ${ }^{1} \mathrm{H}$ NMR (400 MHz, DMSO- $d_{6}$ ): $\delta=7.94$ (br s, $4 \mathrm{H}$ ), 7.58 (br s, $2 \mathrm{H}$ ), 2.36 (s, $3 \mathrm{H}$ ).

\section{1-(3,5-Dimethylpyrazole-1-carboximidoyl)guanidinium Chloride} (1c)

To a solution of 3,5-dimethylpyrazole $(5.0 \mathrm{~g}, 52.0 \mathrm{mmol})$ in water (13 $\mathrm{mL}$ ) was added hydrochloric acid $37 \%(4.60 \mathrm{~mL}, 52.0 \mathrm{mmol})$ and dicyandiamide ( $4.37 \mathrm{~g}, 52.0 \mathrm{mmol})$, and the mixture was refluxed for $3 \mathrm{~h}$. The solution was evaporated to dryness in vacuo and the residue triturated with acetone. White crystalline solid ( $4.9 \mathrm{~g}, 44 \%) .{ }^{1} \mathrm{H}$ NMR $(400$ $\mathrm{MHz}$, DMSO- $d_{6}$ ): $\delta=8.09$ (br s, $4 \mathrm{H}$ ), 8.06 (br s, $2 \mathrm{H}$ ), $6.18(\mathrm{~s}, 1 \mathrm{H}), 2.44$ (s, $3 \mathrm{H}), 2.19$ (s, $3 \mathrm{H})$.

\section{$\mathrm{N}$-Guanyl-O-phenylisourea Hydrochloride (1d) ${ }^{20}$}

Dicyandiamide dihydrochloride was prepared by mixing $0.1 \mathrm{~mol}$ of dicyandiamide with $0.2 \mathrm{~mol}$ of $37 \%$ aqueous $\mathrm{HCl}$ and was cooled to 5 ${ }^{\circ} \mathrm{C}$. Thereafter $0.2 \mathrm{~mol}$ of the acid was added. After $10 \mathrm{~min}$ of stirring, a dense crystalline precipitate of dicyandiamide dihydrochloride was obtained. The precipitate was filtered, washed with acetone, and dried in vacuo for $10 \mathrm{~min}$. The white crystalline solid was used in the next step without further purification.

Phenol (53.5 g, $0.568 \mathrm{~mol}$ ) and dicyandiamide dihydrochloride (16.0 g, $0.102 \mathrm{~mol}$ ) were stirred at $70^{\circ} \mathrm{C}$ for $3 \mathrm{~h}$. The mixture was triturated with toluene, and the crude solid was filtered and washed with diethyl ether. The solid was recrystallized from water. White crystalline solid (7.2 g, 33\%). ${ }^{1} \mathrm{H}$ NMR (400 MHz, DMSO- $d_{6}$ ): $\delta=7.97$ (br s, $6 \mathrm{H}$ ), 7.40 (br s, $2 \mathrm{H}$ ), 7.23 (br s, $3 \mathrm{H}$ ).

\section{1-(Benzotriazole-1-carboximidoyl)guanidinium Chloride (1e)}

To a solution of benzotriazole $(5.00 \mathrm{~g}, 4.20 \mathrm{mmol})$ in water $(10.5 \mathrm{~mL})$ was added hydrochloric acid $37 \%(3.70 \mathrm{~mL}, 4.2 \mathrm{mmol})$ and dicyandiamide ( $3.52 \mathrm{~g}, 42.0 \mathrm{mmol}$ ), and the mixture was refluxed for $24 \mathrm{~h}$. The solution was evaporated to dryness in vacuo and the residue triturated with ethanol, washed with acetone, and dried. White crystalline solid (2.52 g, 25\%). HRMS-ESI: $\mathrm{m} / z[\mathrm{M}+\mathrm{H}]^{+}$calcd for $\mathrm{C}_{8} \mathrm{H}_{10} \mathrm{~N}_{7}{ }^{+}$: 204.09922; found: $340.05914 .{ }^{1} \mathrm{H}$ NMR $\left(400 \mathrm{MHz}\right.$, DMSO- $\left.d_{6}\right): \delta=8.86$ (br s, 2 H), 8.52 (br s, 2 H), 8.46 (br s, 2 H), 8.24 (t, J = 8.3 Hz, 2 H), 7.75 (ddd, $J=8.3,7.0,1.1 \mathrm{~Hz}, 1 \mathrm{H}$ ), 7.59 (ddd, $J=8.1,7.0,1.1 \mathrm{~Hz}, 1 \mathrm{H}$ ). ${ }^{13} \mathrm{C}$ NMR $\left(101 \mathrm{MHz}\right.$, DMSO- $\left.d_{6}\right): \delta=162.4,147.8,145.9,130.9,130.1$, 126.0, 119.9, 114.8 .

\section{N-Guanyl-O-methylisourea Hydroacetate (1f $)^{21}$}

In methanol $(200 \mathrm{~mL})$ dicyandiamide $(43.1 \mathrm{~g}, 0.51 \mathrm{~mol})$ and $\mathrm{Cu}(\mathrm{AcO})_{2} \cdot \mathrm{H}_{2} \mathrm{O}(50 \mathrm{~g}, 0.25 \mathrm{~mol}$ ) were mixed, and the mixture was refluxed for $2 \mathrm{~h}$. After cooling down, the precipitate was filtered off and mixed with $150 \mathrm{~mL}$ of distilled water. $\mathrm{H}_{2} \mathrm{~S}$ was introduced into the suspension until $\mathrm{Cu}^{2+}$ is not observed in the solution. $\mathrm{CuS}$ was filtered off and water was removed in vacuo and treated with isopropanol to give the desired product. White, crystalline solid $(40.5 \mathrm{~g}, 46 \%) .{ }^{1} \mathrm{H}$ NMR (400 MHz, DMSO- $d_{6}$ ): $\delta=9.83$ (br s, 2 H), 7.42 (br s, $4 \mathrm{H}$ ), 3.63 (s, $3 \mathrm{H}), 1.66(\mathrm{~s}, 3 \mathrm{H})$.

\section{Procedures for the Synthesis of the Biguanides}

\section{General Procedure A}

$\mathrm{N}$-Carbamimidoyl-1H-pyrazole-1-carboximidamide $(1.14 \mathrm{~g}, \quad 5.5$ mmol, 1.0 equiv) and the corresponding amine ( $8.25 \mathrm{mmol}, 1.5$ equiv) were dissolved in pyridine $(5.5 \mathrm{~mL})$, and the solution was stirred at 40 
${ }^{\circ} \mathrm{C}$ for 6-24 h. The solution was cooled to r.t., the precipitate was filtered and washed with diethyl ether to obtain a white powder. In some cases, to promote precipitation, pyridine was evaporated with toluene and triturated with diethyl ether to get a solid product.

\section{General Procedure B}

$\mathrm{N}$-Carbamimidoyl-1H-pyrazole-1-carboximidamide $(1.14 \mathrm{~g}, \quad 5.5$ mmol, 1.0 equiv) and the corresponding amine ( $8.25 \mathrm{mmol}, 1.5$ equiv) were dissolved in water $(5.5 \mathrm{~mL})$, and the solution was stirred at $40{ }^{\circ} \mathrm{C}$ for 6-24 h. Water was evaporated, and the residue was triturated with acetone, filtered, and washed with acetone and diethyl ether.

\section{General Procedure C}

S-Methyl-guanylisothiouronium iodide ( $1.43 \mathrm{~g}, 5.5 \mathrm{mmol}, 1.0$ equiv) and the corresponding amine ( $8.25 \mathrm{mmol}, 1.5$ equiv) were dissolved in a $1: 1$ pyridine/toluene mixture $(5.5 \mathrm{~mL})$ and the solution was stirred at $40{ }^{\circ} \mathrm{C}$ for $6 \mathrm{~h}$. The solution was cooled to r.t., the solvent was removed in vacuo, and the residue was triturated with isopropanol, filtered, and washed by diethyl ether to obtain a white powder.

\section{Benzylbiguanide Hydrochloride}

Procedure A: yield 93\%; procedure B: yield 96\%; procedure C: (hydroiodide salt) yield $82 \%$. HPLC $\left(\lambda_{254}\right): t_{\mathrm{R}}=11.5 \mathrm{~min} .{ }^{1} \mathrm{H}$ NMR $(400$ MHz, DMSO- $\left.d_{6}\right): \delta=7.96-7.74(\mathrm{~s}, 1 \mathrm{H}), 7.42-7.21(\mathrm{~m}, 5 \mathrm{H}), 7.01(\mathrm{~s}, 6$ $\mathrm{H}), 4.35(\mathrm{~d}, J=4.8 \mathrm{~Hz}, 2 \mathrm{H})$. Data are in accordance with the literature. ${ }^{3}$

\section{1-Benzyl-1-methylbiguanide Hydrochloride}

Procedure A: yield 69\%; procedure B: yield 96\%. Not visible in HPLC $\left(\lambda_{254}\right) .{ }^{1} \mathrm{H}$ NMR $\left(400 \mathrm{MHz}\right.$, DMSO- $\left.d_{6}\right): \delta=7.41-7.32(\mathrm{~m}, 4 \mathrm{H}), 7.28(\mathrm{t}$, $J=6.9 \mathrm{~Hz}, 3 \mathrm{H}), 6.97(\mathrm{~s}, 4 \mathrm{H}), 4.60(\mathrm{~s}, 2 \mathrm{H}), 2.87(\mathrm{~s}, 3 \mathrm{H})$. Data are in accordance with the literature. ${ }^{3}$

\section{1-(4-Chlorobenzyl)biguanide Hydrochloride}

Procedure A: yield 86\%; procedure B: yield 75\%. $\operatorname{HPLC}\left(\lambda_{254}\right): t_{\mathrm{R}}=\min$. ${ }^{1} \mathrm{H}$ NMR (400 MHz, DMSO- $\left.d_{6}\right): \delta=7.89$ (br s, $\left.1 \mathrm{H}\right), 7.43-7.30(\mathrm{~m}, 4 \mathrm{H})$, $7.03(\mathrm{~s}, 6 \mathrm{H}), 4.33(\mathrm{~d}, J=4.2 \mathrm{~Hz}, 2 \mathrm{H})$. Data are in accordance with the literature. ${ }^{22,23}$

\section{1-(4-Methylbenzyl)biguanide Hydrochloride}

Procedure A: yield 87\%; procedure B: yield 70\%. $\operatorname{HPLC}\left(\lambda_{254}\right): t_{\mathrm{R}}=\min$. ${ }^{1} \mathrm{H}$ NMR $\left(400 \mathrm{MHz}\right.$, DMSO- $\left.d_{6}\right): \delta=7.82($ br s, $1 \mathrm{H}), 7.19(\mathrm{~d}, J=7.9 \mathrm{~Hz}, 2$ H), $7.14(\mathrm{~d}, J=7.9 \mathrm{~Hz}, 2 \mathrm{H}), 7.01($ br s, $6 \mathrm{H}), 4.29(\mathrm{~d}, J=5.9 \mathrm{~Hz}, 2 \mathrm{H})$, $2.28(\mathrm{~s}, 3 \mathrm{H})$. Data are in accordance with the literature. ${ }^{23,24}$

\section{1-(4-Nitrobenzyl)biguanide Hydrochloride}

Procedure A: yield 90\%; procedure B: yield 93\%; HRMS-ESI: $\mathrm{m} / \mathrm{z}$ [M + $\mathrm{H}]^{+}$calcd for $\mathrm{C}_{9} \mathrm{H}_{13} \mathrm{~N}_{6} \mathrm{O}_{2}{ }^{+}:$237.10945; found: 237.10876. HPLC $\left(\lambda_{254}\right)$ : $t_{\mathrm{R}}=\min .{ }^{1} \mathrm{H}$ NMR $\left(400 \mathrm{MHz}, \mathrm{DMSO}-d_{6}\right): \delta=8.21(\mathrm{~d}, J=8.7 \mathrm{~Hz}, 2 \mathrm{H})$, $8.00(\mathrm{t}, J=6.2 \mathrm{~Hz}, 1 \mathrm{H}), 7.58(\mathrm{~d}, J=8.8 \mathrm{~Hz}, 2 \mathrm{H}), 7.07(\mathrm{~s}, 6 \mathrm{H}), 4.50(\mathrm{~d}, J=$ $6.1 \mathrm{~Hz}, 2 \mathrm{H}) .{ }^{13} \mathrm{C}$ NMR $\left(101 \mathrm{MHz}\right.$, DMSO- $\left.d_{6}\right): \delta=160.4,158.4,147.3$, $146.5,128.1$ (2 C), 123.4 (2 C), 43.6.

\section{1-(4-Methoxybenzyl)biguanide Hydrochloride}

Procedure A: yield 95\%; procedure B: yield $82 \%$. $\operatorname{HPLC}\left(\lambda_{254}\right): t_{\mathrm{R}}=\min$. ${ }^{1} \mathrm{H}$ NMR (400 MHz, DMSO- $\left.d_{6}\right): \delta=7.80$ (br s, $1 \mathrm{H}$ ), $7.24(\mathrm{~d}, J=8.6 \mathrm{~Hz}, 1$ H), $7.01(\mathrm{~s}, 4 \mathrm{H}), 6.89$ (d, J = 8.6 Hz, $1 \mathrm{H}), 4.26(\mathrm{~d}, J=5.8 \mathrm{~Hz}, 1 \mathrm{H}), 3.73$ $(\mathrm{s}, 2 \mathrm{H})$. Data are in accordance with the literature. ${ }^{25}$

\section{1-Phenylbiguanide Hydrochloride}

Procedure B: yield 68\%; $\mathrm{HPLC}\left(\lambda_{254}\right): t_{\mathrm{R}}=12.8 \mathrm{~min} .{ }^{1} \mathrm{H} \mathrm{NMR}(200 \mathrm{MHz}$, DMSO- $\left.d_{6}\right): \delta=9.91(\mathrm{~s}, 1 \mathrm{H}), 7.50-7.00(\mathrm{~m}, 10 \mathrm{H})$. Data are in accordance with the literature. ${ }^{3}$

\section{Morpholine Biguanide Hydrochloride}

Procedure A: yield 83\%; procedure B: yield 91\%; procedure C: (hydroiodide salt) yield $82 \%$. HPLC $\left(\lambda_{254}\right): t_{\mathrm{R}}=15.7 \mathrm{~min} .{ }^{1} \mathrm{H}$ NMR $(400$ MHz, DMSO- $\left.d_{6}\right): \delta=7.39$ (s, $\left.2 \mathrm{H}\right), 7.02(\mathrm{~s}, 4 \mathrm{H}), 3.58$ (d, $\left.J=4.6 \mathrm{~Hz}, 4 \mathrm{H}\right)$, $3.45(\mathrm{~d}, J=4.5 \mathrm{~Hz}, 4 \mathrm{H})$. Data are in accordance with the literature. ${ }^{26}$

\section{$\mathrm{N}$-Methylpiperazine Biguanide Hydrochloride}

Procedure A: yield 83\%; procedure B: yield 96\%; procedure C: (hydroiodide salt) yield $97 \%$. HPLC $\left(\lambda_{254}\right): t_{R}=3.99 \mathrm{~min} .{ }^{1} \mathrm{H}$ NMR $(400$ MHz, DMSO- $\left.d_{6}\right): \delta=7.35(\mathrm{~s}, 2 \mathrm{H}), 6.96(\mathrm{~s}, 4 \mathrm{H}), 3.44(\mathrm{t}, J=5.0 \mathrm{~Hz}, 4 \mathrm{H})$, $2.30(\mathrm{t}, J=5.0 \mathrm{~Hz}, 4 \mathrm{H}), 2.17(\mathrm{~s}, 3 \mathrm{H})$. Data are in accordance with the literature. ${ }^{27}$

\section{Ethylbiguanide Hydrochloride}

Procedure A: yield 75\%; procedure B: yield 82\%; $\operatorname{HPLC}\left(\lambda_{254}\right): t_{\mathrm{R}}=$ 15.7 min. ${ }^{1} \mathrm{H}$ NMR (400 MHz, DMSO- $d_{6}$ ): $\delta=7.46(\mathrm{~s}, 1 \mathrm{H}$ ), 6.88 (br s, 6 $\mathrm{H}), 3.10(\mathrm{dt}, J=11.4,5.6 \mathrm{~Hz}, 2 \mathrm{H}), 1.05(\mathrm{t}, J=7.2 \mathrm{~Hz}, 3 \mathrm{H})$. Data are in accordance with the literature, described without $\mathrm{HCl}$ form. ${ }^{28}$

\section{Butylbiguanide Hydrochloride}

Procedure A: yield $86 \%$; procedure B: yield $77 \%$; procedure C: (hydroiodide salt) yield 54\%. HPLC $\left(\lambda_{254}\right): t_{\mathrm{R}}=12.1 \mathrm{~min} .{ }^{1} \mathrm{H}$ NMR $(400$ MHz, DMSO- $\left.d_{6}\right): \delta=7.50(\mathrm{t}, J=5.6 \mathrm{~Hz}, 1 \mathrm{H}), 6.88(\mathrm{br} \mathrm{s}, 6 \mathrm{H}), 3.07(\mathrm{q}, J=$ $6.5 \mathrm{~Hz}, 2 \mathrm{H}$ ), 1.42 (p, $J=7.1 \mathrm{~Hz}, 2 \mathrm{H}), 1.35-1.25(\mathrm{~m}, 2 \mathrm{H}), 0.87$ (t, $J=7.3$ $\mathrm{Hz}, 3 \mathrm{H})$. Data are in accordance with the literature.

\section{Hexylbiguanide Hydrochloride}

Procedure A: yield 86\%; procedure B: yield 92\%. $\operatorname{HPLC}\left(\lambda_{254}\right): t_{R}=9.96$ min. ${ }^{1} \mathrm{H}$ NMR (400 MHz, DMSO- $d_{6}$ ): $\delta=7.58$ (br s, $\left.1 \mathrm{H}\right), 6.97$ (br s, $6 \mathrm{H}$ ), $3.06(\mathrm{t}, J=7.1 \mathrm{~Hz}, 2 \mathrm{H}), 1.52-1.34(\mathrm{~m}, 2 \mathrm{H}), 1.26(\mathrm{~d}, J=11.2 \mathrm{~Hz}, 6 \mathrm{H})$, $0.85(\mathrm{t}, J=6.6 \mathrm{~Hz}, 3 \mathrm{H})$. Data are in accordance with the literature, described in free base form. ${ }^{30}$

\section{(N-Carbamimidoylcarbamimidoyl)phenylalanine}

$\mathrm{N}$-Carbamimidoyl-1H-pyrazole-1-carboximidamide $(1.14 \mathrm{~g}, \quad 5.5$ mmol, 1.0 equiv), DIPEA ( $0.96 \mathrm{~mL}, 5.50 \mathrm{mmol}, 1.0$ equiv), and L-phenylalanine ( $908 \mathrm{mg}, 5.50 \mathrm{mmol}, 1.0$ equiv) were dissolved in water $(5.5 \mathrm{~mL})$, and the solution was stirred at $40{ }^{\circ} \mathrm{C}$ for $24 \mathrm{~h}$. Water was evaporated, and the residue was triturated with $10 \mathrm{~mL}$ of ethanol. The precipitate was collected and washed with ethanol and diethyl ether. White crystalline solid (735 mg, 53\%). HRMS-ESI: $m / z$ [M $+\mathrm{H}]^{+}$calcd for $\mathrm{C}_{11} \mathrm{H}_{16} \mathrm{~N}_{5} \mathrm{O}_{2}{ }^{+}$: 250.12985; found: 250.12911. HPLC $\left(\lambda_{254}\right): t_{\mathrm{R}}=8.5$ min. ${ }^{1} \mathrm{H}$ NMR (400 MHz, DMSO- $\left.d_{6}\right): \delta=7.48$ (br s, $\left.3 \mathrm{H}\right), 7.32-7.20(\mathrm{~m}$, $4 \mathrm{H}), 7.19-6.71(\mathrm{~m}, 4 \mathrm{H}), 4.11$ (br s, $1 \mathrm{H}), 3.18$ (br s, $1 \mathrm{H}), 2.84$ (br s, 1 H). ${ }^{13} \mathrm{C}$ NMR $\left(101 \mathrm{MHz}\right.$, DMSO- $\left.d_{6}\right): \delta=173.9,161.9,159.5,139.9$, 129.0 (2 C), 127.8 (2 C), 125.7, 59.3, 37.2.

\section{Conflict of Interest}

The authors declare no conflict of interest. 


\section{Funding Information}

The authors are grateful for the financial support from the Research Fund of the Cancéropôle Provence-Alpes-Côte d'Azur (PACA) and the SATT-Sud Est (EmA grant - Emergence et Accompagnement). The Centre National de la Recherche Scientifique (CNRS), Université Côte d'Azur, ANR, and Région Sud are also acknowledged for additional funding.

\section{Supporting Information}

Supporting information for this article is available online at https://doi.org/10.1055/a-1681-4544.

\section{References}

(1) Kathuria, D.; Bankar, A. A.; Bharatam, P. V. J. Mol. Struct. 2018, 1152,61

(2) Elmar, B.; Stach, K.; Schmidt, F. H.; Heerdt, R.; Weber, H. US4017539A, 1977.

(3) Mayer, S.; Daigle, D. M.; Brown, E. D.; Khatri, J.; Organ, M. G. J. Comb. Chem. 2004, 6, 776.

(4) Smolka, A.; Friedreich, A. Monatsh. Chem. 1888, 9, 227.

(5) Tonelli, M.; Espinoza, S.; Gainetdinov, R. R.; Cichero, E. Eur. J. Med. Chem. 2017, 127, 781.

(6) van Kuijk, S. J. A.; Parvathaneni, N. K.; Niemans, R.; van Gisbergen, M. W.; Carta, F.; Vullo, D.; Pastorekova, S.; Yaromina, A.; Supuran, C. T.; Dubois, L. J.; Winum, J.-Y.; Lambin, P. Eur. J. Med. Chem. 2017, 127, 691.

(7) Suyama, T.; Soga, T.; Miyauchi, K. A. Nippon Kagaku Kaishi 1989, 5,884 .

(8) Obianom, O. N.; Coutinho, A. L.; Yang, W.; Yang, H.; Xue, F.; Shu, Y. Mol. Pharm. 2017, 14, 2726.

(9) Kim, S. W.; Kim, H. W.; Yoo, S. H.; Lee, J. S.; Heo, H. J.; Lee, H. B.; Kook, J. A.; Lee, Y. W.; Kim, M. J.; Cho, W. WO2015160220A1, 2015.

(10) Fortun, S.; Schmitzer, A. R. ACS Omega 2018, 3, 1889.
(11) Fortun, S.; Schmitzer, A. R. Can. J. Chem. 2020, 98, 251.

(12) Guo, Z.; Cainmldge, A. N.; Mckiilop, A. Tetrahedron Lett. 1999, 40, 6999.

(13) Chen, H. Y.; Zhao, M.; Tan, J.-H.; Huang, Z.-S.; Liu, G.-F.; Ji, L.-N.; Mao, Z.-W. Tetrahedron 2014, 70, 2378.

(14) Yan, Q.; Zhao, Y. Chem. Sci. 2015, 6, 4343.

(15) Hao, X.; Sang, W.; Hu, J.; Yan, Q. ACS Macro Lett. 2017, 6, 1151.

(16) Shuhui, C.; Zhifei, F.; Jian, L.; Miaorong, L.; Yang, Z. AU2017306487A1, 2018

(17) Vaillancourt, V. A.; Larsen, S. D.; Tanis, S. P.; Burr, J. E.; Connell, M. A.; Cudahy, M. M.; Evans, B. R.; Fisher, P. V.; May, P. D.; Meglasson, M. D.; Robinson, D. D.; Stevens, F. C.; Tucker, J. A.; Vidmar, T. J.; Yu, J. H. J. Med. Chem. 2001, 44, 1231.

(18) Igashira-Kamiyama, A.; Kajiwara, T.; Nakano, M.; Konno, T.; Ito, T. Inorg. Chem. 2009, 48, 11388.

(19) Eilingsfeld, H.; Scheuermann, H. Chem. Ber. 1967, 100, 1874.

(20) Bando, S.; Ichikawa, E.; Odo, K. J. Synth. Org. Chem., Jpn. 1970, 28 , 521.

(21) Kawano, K. Bull. Kyushu Inst. Technol., Math., Nat. Sci. 1962, 12, 69.

(22) Kim, H. W.; Jeong, J. K.; Lee, J. S.; Heo, H. J.; Lee, H. B.; Kook, J. A.; Kim, S. W. WO2016080810 A2, 2016.

(23) Shapiro, S. L.; Parrino, V. A.; Freedman, L. J. Am. Chem. Soc. 1959, $81,3728$.

(24) Kim, S. W.; Kim, H. W.; Yoo, S. H.; Lee, J. S.; Heo, H. J.; Lee, H. B.; Kook, J. A.; Lee, Y. W.; Kim, M. J.; Cho, W. US2017073331 A1, 2015.

(25) Ma, X.; Tan, S.-T.; Khoo, C.-L.; Sim, H.-M.; Chan, L.-W.; Chui, W.-K. Bioorg. Med. Chem. Lett. 2011, 21, 5428.

(26) Makowska, A.; Saczewski, F.; Bednarski, P. J.; Saczewski, J.; Balewski, Ł. Molecules 2018, 23, 1.

(27) Husain, M. I.; Srivastava, V. P. Indian J. Chem., Sect. B. Org. Chem. Incl. Med. Chem. 1984, 23B, 789.

(28) Corbellini, A.; Lugaro, G.; Giannattasio, G.; Torti, G. Arch. Ital. Patol. Clin. Tumori 1967, 10, 197.

(29) Shapiro, S. L.; Freedman, L. US2961377A, 1957.

(30) Kim, H. W.; Jeong, J. K.; Lee, J. S.; Hye, J. H.; Kook, J. A.; Kim, S. W. US2020/0277255 A1, 2020. 